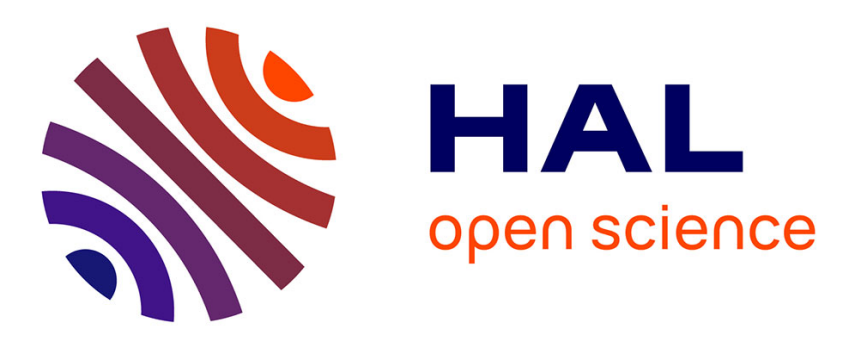

\title{
A Method to Monitor the Introduction of Posttranscriptional Modifications in tRNAs with NMR Spectroscopy
}

\author{
Alexandre Gato, Marjorie Catala, Carine Tisné, Pierre Barraud
}

\section{To cite this version:}

Alexandre Gato, Marjorie Catala, Carine Tisné, Pierre Barraud. A Method to Monitor the Introduction of Posttranscriptional Modifications in tRNAs with NMR Spectroscopy. Methods in Molecular Biology, 2021, pp.307 - 323. 10.1007/978-1-0716-1374-0_19 . hal-03257241

\section{HAL Id: hal-03257241 \\ https://hal.science/hal-03257241}

Submitted on 10 Jun 2021

HAL is a multi-disciplinary open access archive for the deposit and dissemination of scientific research documents, whether they are published or not. The documents may come from teaching and research institutions in France or abroad, or from public or private research centers.
L'archive ouverte pluridisciplinaire HAL, est destinée au dépôt et à la diffusion de documents scientifiques de niveau recherche, publiés ou non, émanant des établissements d'enseignement et de recherche français ou étrangers, des laboratoires publics ou privés. 


\title{
A Method to Monitor the Introduction of Posttranscriptional Modifications in tRNAs with NMR Spectroscopy
}

\author{
Alexandre Gato ${ }^{a}$, Marjorie Catala ${ }^{a}$, Carine Tisné ${ }^{a} \&$ Pierre Barraud $^{\mathrm{a}, *}$ \\ a Expression génétique microbienne, UMR 8261, CNRS, Université de Paris, Institut de biologie physico-chimique \\ (IBPC), 13 rue Pierre et Marie Curie, FR-75005 Paris, France
}

\begin{abstract}
During their biosynthesis, transfer RNAs (tRNAs) are decorated all along their sequence with a large number of posttranscriptional chemical modifications. Methods to directly detect the introduction of posttranscriptional modifications during tRNA maturation are rare and do not easily bring information on the temporality of modification events. Here, we report a methodology, using NMR as a tool to monitor tRNA maturation in a nondisruptive and continuous fashion in cellular extracts. This method requires the production for NMR spectroscopy of substrate tRNA transcripts devoid of modifications and of active cell extracts containing the cellular enzymatic activities. The present protocol describes these different aspects of our method and reports the time-resolved NMR monitoring of the yeast tRNA ${ }^{\text {Phe }}$ maturation as an example. The NMR-based methodology presented here could be adapted to investigate diverse features in tRNA maturation.
\end{abstract}

To cite this article: A. Gato et al. (2021) In: McMahon M. (eds) RNA Modifications. Methods in Molecular Biology, vol 2298. Humana, New York, NY. doi:10.1007/978-1-0716-1374-0 19

This is a postprint of an article published in Methods in Molecular Biology. The final authenticated version is available online at: https://doi.org/10.1007/978-1-0716-1374-0_19

Key words:

transfer RNA, tRNA, posttranscriptional modifications, RNA modifications, yeast, RNA transcription, NMR spectroscopy, yeast extract, time-resolved NMR, in extract NMR

\section{Introduction}

Synthesis and maturation of transfer RNAs (tRNAs) involve posttranscriptional chemical modifications of their nucleotides. These modifications occur at specific sites in a tightly controlled manner, which ensures that the tRNA biogenesis process effectively leads to the formation of mature and functional tRNAs [1-4]. Currently, over 140 posttranscriptional modifications are reported in RNAs, the

\footnotetext{
* Corresponding author

Email address: pierre.barraud@cnrs.fr (Pierre Barraud). 
vast majority being found in tRNAs $[5,6]$. This family of RNAs displays not only the largest variety of posttranscriptional decoration, but also the highest density of modification per RNA molecule, with $~ 8-$ $25 \%$ of modified nucleotides in tRNAs depending on the organisms $[7,8]$. Notably, all tRNA functions within cells are affected by modifications. In particular, modifications in and around the anticodon are implicated in the decoding process $[1,9,10]$. In addition, some modifications control cleavages producing tRNA fragments [11, 12]. And finally, cellular stress can result in changes in tRNA modifications, which can lead to translational reprogramming $[13,14]$.

Even though modifications are central in tRNA biology, methods to directly detect their introduction during tRNA biosynthesis are rare and do not easily provide information on the temporality of modification events. With the aim of filling this gap, we have developed a methodology, using NMR as a tool to monitor tRNA maturation in a nondisruptive and continuous manner [15]. Briefly, introducing isotope-labeled tRNAs into unlabeled cell extracts containing the cellular enzymatic activities combined with the use of isotope filters in NMR experiments, enables the detection of the tRNA of interest within the complex cell extract environment (Figure 1). RNA modification events are directly monitored in a time-resolved fashion, by measuring successive NMR experiments on a single sample directly incubated in the NMR spectrometer.

In this chapter, we describe the detailed procedure for monitoring tRNA maturation in cell extracts with NMR spectroscopy. We demonstrate our methodology with the maturation of the yeast tRNA ${ }^{\text {Phe }}$ in yeast extracts. Our methodology consists of three steps (Figure 1). In the first step, a ${ }^{15} \mathrm{~N}$-labeled tRNA sample is produced by in vitro transcription with ${ }^{15} \mathrm{~N}$-labeled nucleotides and purified by ionexchange chromatography (Figure 1; step 1). After dialysis and concentration, the ${ }^{15} \mathrm{~N}$-labeled tRNA sample is ready for further use. In the second step, an unlabeled cellular extract is produced from the lysis of a cell culture (Figure 1; step 2). To preserve as far as possible the cellular enzymatic activities in the extract, cell lysis is performed under gentle conditions and in the presence of anti-proteases. After ultracentrifugation of the cell debris, active unlabeled cellular extracts are obtained. In the third step, the NMR monitoring of tRNA maturation is performed (Figure 1; step 3). An in extract NMR sample is produced by mixing the ${ }^{15} \mathrm{~N}$-labeled tRNA sample obtained in step 1 with the unlabeled cell extract obtained in step 2. This sample is incubated directly in the NMR spectrometer and series of NMR experiments are measured in order to monitor tRNA maturation events in a time-resolved fashion (Figure 1; step 3). In the NMR spectra, the progressive appearance of new signals and the correlated disappearance of signals from the unmodified tRNA sample are the signature of chemical modifications being introduced in the initial transcript. Since NMR spectra are measured as a timecourse series, our methodology enables the identification of early and latter modifications events. Overall, NMR spectroscopy provides the means to observe sequential orders in the introduction of modifications along the tRNA maturation pathway.

\section{Materials}

All solutions are prepared using reagents of highest available purity and with ultrapure deionized water. Particular care should always be taken to avoid RNase contamination during preparation of reagents that are required for the RNA transcription reaction (see Note 1). The use of ultrapure deionized water is sufficient to assure RNase-free condition, provided that the water purification system is well maintained. All reagents required for RNA transcription and cellular extract preparation are stored at $-20^{\circ} \mathrm{C}$, unless indicated otherwise (see Note 2).

\section{1. tRNA transcription and purification}

1. Commercial or in-house produced (see Note 3) T7 RNA polymerase (stock at $1 \mathrm{mg} / \mathrm{mL}$ stored at $-20^{\circ} \mathrm{C}$ in $20 \mathrm{mM}$ Na-phosphate $\mathrm{pH} 7.7,100 \mathrm{mM} \mathrm{NaCl}, 10 \mathrm{mM}$ DTT, $1 \mathrm{mM} \mathrm{EDTA}, 50 \%$ (v/v) glycerol). 
2. In vitro $\mathrm{T} 7$ transcription buffer concentrated 20 times (TB20x): $400 \mathrm{mM}$ Tris- $\mathrm{HCl} \mathrm{pH}$ 8.0, $10 \mathrm{mM}$ spermidine, $50 \mathrm{mM}$ DTT, $0.1 \%(\mathrm{v} / \mathrm{v})$ Triton X-100 in water. Store at $-20^{\circ} \mathrm{C}$.

3. Stock solution of unlabeled ATP and CTP at $100 \mathrm{mM}$ and $\mathrm{pH} 8.0$ (e.g. Jena Bioscience, catalog numbers: NU-1010 and NU-1011). Store at $-20^{\circ} \mathrm{C}$.

4. Stock solution of ${ }^{15} \mathrm{~N}$-labeled UTP and GTP at $100 \mathrm{mM}$ (Cambridge Isotope Laboratories, catalog numbers: NLM-4270-CA and NLM-4268-CA). Store at $-20^{\circ} \mathrm{C}$.

5. DNA oligonucleotide of high purity for use as template for the yeast tRNA ${ }^{\text {Phe }}$ transcription at $100 \mu \mathrm{M}$ in water (see Note 4). For the yeast tRNA ${ }^{\text {Phe }}$, use an oligonucleotide with the following sequence: $5^{\prime}$ TGG TGC GAA TTC TGT GGA TCG AAC ACA GGA CCT CCA GAT CTT CAG TCT GGC GCT CTC CCA ACT GAG CTA AAT CCG CTA TAG TGA GTC GTA TTA $3{ }^{\prime}$.

6. DNA oligonucleotide of high purity for use as $\mathrm{T} 7$ promotor primer at $100 \mu \mathrm{M}$ in water (see Note 5). For example: $5^{\prime}$ TAA TAC GAC TCA CTA TAG $3^{\prime}$.

7. Sterile syringe filters $0.22 \mu \mathrm{m}$.

8. $\mathrm{MgCl}_{2}$ at $280 \mathrm{mM}$ in water. Sterilize by filtration with $0.22 \mu \mathrm{m}$ filter and store at $-20^{\circ} \mathrm{C}$.

9. GMP pH 7.5 at $80 \mathrm{mM}$ in water. Sterilize by filtration with $0.22 \mu \mathrm{m}$ filter and store at $-20^{\circ} \mathrm{C}$.

10. Water bath with temperature control.

11. Ethylenediaminetetraacetic acid (EDTA) prepared at $0.5 \mathrm{M} \mathrm{pH} 8.0$ in water. Store at room temperature.

12. ÄKTA Purifier (GE Healthcare) or similar chromatographic system.

13. MonoQ 10/100 GL column (GE Healthcare).

14. Purification buffer A: $25 \mathrm{mM}$ Na-phosphate $\mathrm{pH}$ 6.5, $50 \mathrm{mM} \mathrm{NaCl}, 5 \mathrm{mM} \mathrm{MgSO}$ (filtrate with $0.22 \mu \mathrm{m}$ filter).

15. Purification buffer B: $25 \mathrm{mM}$ Na-phosphate $\mathrm{pH} 6.5,1 \mathrm{M} \mathrm{NaCl}$ (filtrate with $0.22 \mu \mathrm{m}$ filter).

16. NMR buffer: $10 \mathrm{mM}$ Na-phosphate $\mathrm{pH} 6.5,10 \mathrm{mM} \mathrm{MgCl}_{2}$.

17. NMR buffer stock solutions: $500 \mathrm{mM}$ Na-phosphate $\mathrm{pH}$ 6.5, $1 \mathrm{M} \mathrm{MgCl}_{2}$.

18. Dialysis sacks with 3.5 kDa MWCO (e.g. Spectra/Por 3 Dialysis Tubing Spectra/Por).

19. Standard closures for dialysis tubing.

20. Concentrators Amicon Ultra-15 MWCO 10 kDa (Millipore/Merck).

21. Ultrapure deionized water. 


\subsection{Cellular extract preparation}

1. Ampicillin stock solution at $100 \mathrm{mg} / \mathrm{mL}$ in water. Store at $-20^{\circ} \mathrm{C}$.

2. YEPD-Ampicillin agar plates: Dissolve $10 \mathrm{~g}$ of yeast extract, $20 \mathrm{~g}$ of peptone, and $20 \mathrm{~g}$ of agar in $950 \mathrm{~mL}$ of water and sterilize by autoclaving. Prepare a solution of $40 \%(\mathrm{w} / \mathrm{v})$ of glucose in water and sterilize by filtration with $0.22 \mu \mathrm{m}$ filter. Add $50 \mathrm{~mL}$ of the sterile-filtered glucose solution in the autoclaved medium to obtain $1 \mathrm{~L}$ of YEPD agar medium containing $2 \%(\mathrm{w} / \mathrm{v})$ of glucose. Allow the solution to cool to $\sim 50^{\circ} \mathrm{C}$ and add ampicillin at a final concentration of $100 \mu \mathrm{g} / \mathrm{mL}$. Mix well and pour $25 \mathrm{~mL}$ of the solution per Petri dish. Plates can be stored upside down at $4^{\circ} \mathrm{C}$ for several weeks.

3. YEPD medium: Dissolve $10 \mathrm{~g}$ of yeast extract and $20 \mathrm{~g}$ of peptone in $950 \mathrm{~mL}$ of water and sterilize by autoclaving. Prepare a solution of $40 \%(\mathrm{w} / \mathrm{v})$ of glucose in water and sterilize by filtration with $0.22 \mu \mathrm{m}$ filter. Solutions can be stored for months at room temperature. Add $50 \mathrm{~mL}$ of the sterilefiltered glucose solution in the autoclaved medium to obtain $1 \mathrm{~L}$ of YEPD medium containing $2 \%$ $(\mathrm{w} / \mathrm{v})$ of glucose.

4. Glycerol stock of c13-ABYS- 86 S. cerevisiae strain stored at $-80^{\circ} \mathrm{C}$ (see Note 6 ).

5. Static and shaking incubators at $30^{\circ} \mathrm{C}$. Sterile $100 \mathrm{~mL}$, and 2 L Erlenmeyer flasks.

6. Spectrophotometer to measure the absorbance at $600 \mathrm{~nm}$ (OD600).

7. Centrifugation bottles for cell harvesting and S30 cell extract preparation and corresponding rotors (e.g. Beckman Coulter JA-10 and JA-20). Ultracentrifugation bottles for S100 cell extract preparation and corresponding rotor (e.g. Beckman Coulter Type $70.1 \mathrm{Ti}$ ).

8. Centrifuge and Ultracentrifuge with temperature control that allows cooling to $4^{\circ} \mathrm{C}$.

9. Mechanical device to disrupt yeast cells such as an Eaton press or a French press (see Note 7).

10. Lysis buffer: $25 \mathrm{mM} \mathrm{KH} \mathrm{PO}_{4} / \mathrm{Na}_{2} \mathrm{HPO}_{4} \mathrm{pH} 7.0,10 \mathrm{mM} \mathrm{MgCl}$, $0.1 \mathrm{mM}$ EDTA. Sterilize by filtration with $0.22 \mu \mathrm{m}$ filter and divide into aliquots of $10 \mathrm{~mL}$. Store at $-20^{\circ} \mathrm{C}$.

11. DTT stock solution at $1 \mathrm{M}$ : Dissolve $3.085 \mathrm{~g}$ of 1 ,4-dithio-DL-threitol into $20 \mathrm{~mL}$ of $10 \mathrm{mM}$ sodium acetate $\mathrm{pH} 5.2$. Sterilize by filtration with $0.22 \mu \mathrm{m}$ filter and divide into aliquots of $1 \mathrm{~mL}$. Store at $-20^{\circ} \mathrm{C}$.

12. Phenylmethanesulfonyl fluoride (PMSF) solution at $100 \mathrm{mM}$ in isopropanol. Store at $4^{\circ} \mathrm{C}$.

13. Benzamidine stock solution at $500 \mathrm{mM}$ : Dissolve $437 \mathrm{mg}$ of benzamidine hydrochloride into $5 \mathrm{~mL}$ of water. Sterilize by filtration with $0.22 \mu \mathrm{m}$ filter and divide into aliquots of $500 \mu \mathrm{L}$. Store at $-20^{\circ} \mathrm{C}$.

14. Antiprotease stock solutions concentrated 5000x: On one hand, dissolve $5 \mathrm{mg}$ of leupeptin and 5 $\mathrm{mg}$ of antipain into $1 \mathrm{~mL}$ of water and divide into aliquots of $200 \mu \mathrm{L}$. On the other hand, dissolve $5 \mathrm{mg}$ of pepstatine A and $5 \mathrm{mg}$ of chymostatin into $1 \mathrm{~mL}$ of DMSO and divide into aliquots of 200 $\mu \mathrm{L}$. Store both antiprotease stock solutions at $-20^{\circ} \mathrm{C}$.

15. Liquid nitrogen (see Note 8). 
1. Maturation buffer concentrated ten times (MB10x): $1.5 \mathrm{M} \mathrm{NaH} \mathrm{PO}_{4} / \mathrm{K}_{2} \mathrm{HPO}_{4} \mathrm{pH} 7.5,50 \mathrm{mM}$ $\mathrm{NH}_{4} \mathrm{Cl}, 20 \mathrm{mM}$ DTT, $1 \mathrm{mM}$ EDTA in water (see Note 9). Sterilize by filtration with $0.22 \mu \mathrm{m}$ filter and divide into aliquots of $500 \mu \mathrm{L}$. Store at $-20^{\circ} \mathrm{C}$.

2. $\mathrm{MgCl}_{2}$ at $1 \mathrm{M}$ in water. Sterilize by filtration with $0.22 \mu \mathrm{m}$ filter and divide into aliquots of 500 $\mu \mathrm{L}$. Store at $-20^{\circ} \mathrm{C}$.

3. Stock solution of S-adenosyl-L-methionine (SAM) at $100 \mathrm{mM}$ (see Note 10) in a $5 \mathrm{mM} \mathrm{H}_{2} \mathrm{SO}_{4}$ solution (see Note 11). Divide into aliquots of $25 \mu \mathrm{L}$. Store at $-20^{\circ} \mathrm{C}$ for up to $4-6$ months.

4. Stock solution of ATP at $100 \mathrm{mM}$ and pH 8.0 (e.g. Jena Bioscience, catalog number: NU-1010). Store at $-20^{\circ} \mathrm{C}$.

5. Stock solution of $\beta$-Nicotinamide adenine dinucleotide $2^{\prime}$-phosphate reduced (NADPH) at $100 \mathrm{mM}$ (see Note 12) and $\mathrm{pH} 8$ in water (see Note 13). Divide into aliquots of $25 \mu \mathrm{L}$. Store at $-20^{\circ} \mathrm{C}$ for up to 1-2 months.

6. Deuterium oxide 99.96\% ( $\left.\mathrm{D}_{2} \mathrm{O}\right)$ (e.g. Eurisotop, catalog number: D215B).

7. $5 \mathrm{~mm}$ Shigemi NMR tubes (see Note 14).

8. Manual centrifuge equipped with a swing-out rotor and $15 \mathrm{~mL}$ conical tube adaptors for the centrifugation of NMR tubes (e.g. Hettich, catalog numbers: HET-1011 and HET-1014).

9. Solution-state NMR spectrometer operating at $600 \mathrm{MHz}$ or higher, equipped with a cryogenically cooled triple-resonance probe with z-axis gradients.

10. RNase-free water

\section{Methods}

\section{1. $t R N A$ transcription and purification}

The optimal $\mathrm{T} 7$ in vitro transcription conditions depend greatly on the $\mathrm{MgCl}_{2}$ and $\mathrm{NTP}$ concentrations. The $\left[\mathrm{MgCl}_{2}\right] /[\mathrm{NTP}]$ ratio should be adjusted to optimize the yield of the RNA of interest. We recommend testing small-scale reactions $($ e.g. $40 \mu \mathrm{L})$ before large-scale production of RNAs $(5-20$ $\mathrm{mL}$ ) (see Note 15). For large scale in vitro transcription, up-scale the best conditions determined with small-scale reactions. In our hands, large amount of unmodified yeast tRNA ${ }^{\text {Phe }}{ }^{15} \mathrm{~N}$-labeled on Us and Gs (see Note 16) sufficient for monitoring its maturation with NMR, can be obtained from a $10 \mathrm{~mL}$ transcription reaction as described here.

1. Prepare the large-scale transcription reaction of $10 \mathrm{~mL}$ in a $50 \mathrm{~mL}$ conical tube as follow: $40 \mu \mathrm{L}$ of DNA template pre-mixed with the T7 promotor primer at a 1:1 ratio (stock at $50 \mu \mathrm{M}$ ), $500 \mu \mathrm{L}$ of TB20x transcription buffer, $500 \mu \mathrm{L}$ of non-labeled ATP (stock at $100 \mathrm{mM}$ ), $500 \mu \mathrm{L}$ of non-labeled CTP (stock at $100 \mathrm{mM}$ ), $500 \mu \mathrm{L}$ of ${ }^{15} \mathrm{~N}$-labeled UTP (stock at $100 \mathrm{mM}$ ), $500 \mu \mathrm{L}$ of ${ }^{15} \mathrm{~N}$-labeled GTP (stock at $100 \mathrm{mM}$ ), $1300 \mu \mathrm{L}$ of $\mathrm{MgCl}_{2}$ (stock at $280 \mathrm{mM}$ ), $500 \mu \mathrm{L}$ of GMP (stock at $80 \mathrm{mM}$ ), $250 \mu \mathrm{L}$ of T7 RNA polymerase (stock at $1 \mathrm{mg} / \mathrm{mL}$ ), and complete with ultrapure deionized water to $10 \mathrm{~mL}$. 
2. Incubate in a water bath for $\sim 3-4 \mathrm{~h}$ at $37^{\circ} \mathrm{C}$ (see Note 17 ).

3. Stop the reaction by adding 1.0-1.5 mL of $0.5 \mathrm{M}$ EDTA pH 8.0 (see Note 18). The transcription reaction can be stored few days at $-20^{\circ} \mathrm{C}$ until its purification or purified directly as described below.

4. Wash the purification system (ÄKTA Purifier or equivalent FPLC purification system) and the column (MonoQ 10/100 GL) with 0.5 M NaOH and rinse them extensively with water (see Note 19). Then, equilibrate the MonoQ column in purification buffer A.

5. Filtrate the large-scale transcription sample with $0.22 \mu \mathrm{m}$ filter and load up to 5-6 $\mathrm{mL}$ of the transcription sample (see Note 20) on the MonoQ column previously equilibrated with purification buffer $\mathrm{A}$ at a flow rate of $2 \mathrm{~mL} / \mathrm{min}$.

6. Elute the tRNA transcript from the MonoQ column with a $20 \%-80 \%$ gradient of purification buffer B over $75 \mathrm{~mL}(\sim 10$ column volumes) at a flow rate of $3 \mathrm{~mL} / \mathrm{min}$. Collect $1 \mathrm{~mL}$ fractions. Transcribed yeast tRNA ${ }^{\text {Phe }}$ is usually eluted between $50 \%$ and $55 \%$ of buffer B (see Note 21).

7. Repeat steps 5 and 6 with the remaining of the $10 \mathrm{~mL}$ large-scale transcription, and pool the fractions containing the tRNA of interest from both purification runs.

8. Dialyze extensively the pooled fractions of yeast $\mathrm{tRNA}^{\text {Phe }}$ in a dialysis sack against $1 \mathrm{mM} \mathrm{Na}-$ phosphate $\mathrm{pH} 6.5$ (see Note 22).

9. Recover the desalted tRNA ${ }^{\text {Phe }}$ in a $50 \mathrm{~mL}$ conical plastic tube and refold it by heating the sample at $95^{\circ} \mathrm{C}$ for $5 \mathrm{~min}$ and letting it cool down slowly at room temperature. Add NMR buffer stock solutions (e.g. $500 \mathrm{mM} \mathrm{Na-phosphate} \mathrm{pH} 6.5$ and $1 \mathrm{M} \mathrm{MgCl}_{2}$ ) to place the refolded sample in the final NMR buffer, namely $10 \mathrm{mM}$ Na-phosphate $\mathrm{pH} 6.5$ and10 $\mathrm{mM} \mathrm{MgCl}_{2}$ (see Note 23).

10. Concentrate the yeast tRNA ${ }^{\text {Phe }}$ sample in the NMR buffer up to 1.5-2.0 mM using Amicon concentrators of $10 \mathrm{kDa}$. Typically, a $10 \mathrm{~mL}$ transcription with ${ }^{15} \mathrm{~N}$-labeled Us and Gs provides a final NMR sample of $300 \mu \mathrm{L}$ at $\sim 1.8 \mathrm{mM}$, corresponding to $0.5-0.6 \mu \mathrm{mol}$ of purified tRNA. Store the concentrated yeast tRNA ${ }^{\text {Phe }}$ NMR sample at $-20^{\circ} \mathrm{C}$ until needed (see Note 24 ).

\subsection{Cellular extract preparation}

All steps after cell harvest are performed on ice, unless indicated otherwise. Pre-cool centrifugation bottles, rotors and centrifuges before usage.

1. Streak yeast c13-ABYS-86 cells from glycerol stock on YEPD-Ampicillin agar plate and incubate the plate in a static incubator at $30^{\circ} \mathrm{C}$ for $\sim 2$ days until the colonies appear.

2. Start a preculture by transferring an individual colony with a sterile inoculation loop into a 100 $\mathrm{mL}$ Erlenmeyer containing $25 \mathrm{~mL}$ of YEPD medium supplemented with $100 \mu \mathrm{g} / \mathrm{mL}$ of ampicillin. Incubate the preculture in a shaking incubator at $30^{\circ} \mathrm{C}$ and $200 \mathrm{rpm}$ for $20 \mathrm{~h}$.

3. Measure the $\mathrm{OD}_{600}$ of the preculture. Start a culture with an $\mathrm{OD}_{600}$ of 0.15 by transferring the appropriate volume of preculture into a $2 \mathrm{~L}$ Erlenmeyer containing $500 \mathrm{~mL}$ of YEPD medium. Incubate the culture in a shaking incubator at $30^{\circ} \mathrm{C}$ and $200 \mathrm{rpm}$ for $24 \mathrm{~h}$.

4. Harvest the cells by a $20 \mathrm{~min}$ centrifugation at $3500 \times g$ at room temperature in $500 \mathrm{~mL}$ centri- 
fugation bottles. Resuspend the cell pellet with $40 \mathrm{~mL}$ of cold water and transfer the suspension into a $50 \mathrm{~mL}$ conical tube. Centrifuge cells at $3500 \times \mathrm{g}$ for $20 \mathrm{~min}$ at $4^{\circ} \mathrm{C}$. Weight the cell pellet (see Note 25). Store the cells at $-80^{\circ} \mathrm{C}$ until needed for cellular extract preparation.

5. Add one equivalent volume of lysis buffer (i.e. $1 \mathrm{~mL}$ of lysis buffer per $\mathrm{g}$ of yeast cells) to the frozen cells on ice and re-suspend cells gently. Add DTT at a final concentration of $2 \mathrm{mM}$, PMSF and benzamidine both at a final concentration of $1 \mathrm{mM}$, and leupeptin, antipain, pepstatin $\mathrm{A}$ and chymostatin each at a final concentration of $1 \mu \mathrm{g} / \mathrm{mL}$.

6. Lyse the cells by two sequential passages in a pre-cooled Eaton pressure chamber at $-80^{\circ} \mathrm{C}$ operated via a hydraulic press with a working pressure of 20,000-30,000 psi. Alternatively, cells may be lysed by two sequential passages in a pre-cooled French press at $4^{\circ} \mathrm{C}$ operating at a pressure of 10,000-20,000 psi (see Note 7).

7. Evaluate the volume of lysed cell suspension recovered after lysis and add again DTT, PMSF, benzamidine, leupeptin, antipain, pepstatin A and chymostatin to double the previously mentioned final concentrations (see Note 26).

8. Centrifuge the disrupted cells at $30,000 \times g$ for $1 \mathrm{~h}$ at $8^{\circ} \mathrm{C}$. Carefully recover the supernatant and transfer it into a clean ultra-centrifugation bottle. Ultra-centrifuge the yeast S30 cell extract at $100,000 \times g$ for $1 \mathrm{~h}$ at $8^{\circ} \mathrm{C}$. Transfer $250 \mu \mathrm{L}$ aliquots of the supernatant into $1.5 \mathrm{~mL}$ safe-lock tubes. Snap freeze the S100 yeast extract aliquots into liquid nitrogen (see Note 8) and store the cellular extracts at $-80^{\circ} \mathrm{C}$ until needed (see Note 27 ).

\subsection{NMR monitoring of tRNA maturation}

The monitoring of tRNA maturation can simply be monitored by adding the unmodified ${ }^{15} \mathrm{~N}$-labeled tRNA prepared in step 1 into the unlabeled cellular extract prepared in step 2 (Figure 1). In our hands, with the yeast tRNA ${ }^{\text {Phe }}$, sufficient signal-to-noise ratio in NMR measurements can be achieved with a concentration of ${ }^{15} \mathrm{~N}$-labeled tRNA of $40 \mu \mathrm{M}$ in the cellular extract (see Note 28). Additionally, cofactors of modification enzymes should be added to the reaction to ensure efficient activity of the cell extract. In practice, we add S-adenosyl-L-methionine (SAM), the almost universal methyl donor used by RNA methyltransferases, and reduce nicotinamide adenine dinucleotide phosphate (NADPH), a hydride donor implicated in the formation of dihydrouridines. All components of the maturation reaction should be prepared and mixed together on ice. The ${ }^{15} \mathrm{~N}$-labeled tRNA must be added last and the delay from its mixing to the starting of the NMR experiments must be as quick as possible and kept shorter than $\sim 5-10$ min (see Note 29). Incubation is done directly in the NMR spectrometer, and a series of NMR experiments are measured in a time-resolved fashion in order to visualize the sequential order of tRNA modification events (Figure 2). Although the observation of NMR chemical shift changes that correspond to modification events is easily performed at this step, the interpretation of these changes in terms of posttranscriptional modifications is not necessarily straightforward and might necessitate in-depth NMR studies (see Note 30 ).

1. Prepare the tRNA maturation reaction of $280 \mu \mathrm{L}$ in a $1.5 \mathrm{~mL}$ tube on ice as follow: $185 \mu \mathrm{L}$ of yeast cellular extract prepared in Subheading 3.2, $28 \mu \mathrm{L}$ of MB10x maturation buffer, $1.4 \mu \mathrm{L}$ of $\mathrm{MgCl}_{2}$ (stock at $1 \mathrm{M} ; 5 \mathrm{mM}$ final), $11.2 \mu \mathrm{L}$ of SAM (stock at $100 \mathrm{mM} ; 4 \mathrm{mM}$ final), $11.2 \mu \mathrm{L}$ of ATP (stock at $100 \mathrm{mM} ; 4 \mathrm{mM}$ final), $11.2 \mu \mathrm{L}$ of NADPH (stock at $100 \mathrm{mM} ; 4 \mathrm{mM}$ final), $14 \mu \mathrm{L}$ of $\mathrm{D}_{2} \mathrm{O}\left(5 \%\right.$ (v/v) final), $6.3 \mu \mathrm{L}$ of ${ }^{15} \mathrm{~N}$-labeled yeast tRNA ${ }^{\text {Phe }}$ prepared in Subheading 3.1 (stock at $1.8 \mathrm{mM} ; 40 \mu \mathrm{M}$ final), and complete with RNase-free water to $280 \mu \mathrm{L}$ (see Note 31). 
2. Quickly transfer the tRNA maturation mix to a $5 \mathrm{~mm}$ Shigemi tube. Spin down the reaction mix using a manual centrifuge adapted for NMR tube centrifugation. Put the Shigemi plunger in place and maintain it in position with sealing plastic film (e.g. Parafilm). Insert the NMR tube into the NMR spectrometer probe previously equilibrated at $30^{\circ} \mathrm{C}$.

3. Perform a rapid adjustment of the shims and quickly start the series of $2 \mathrm{D}\left({ }^{1} \mathrm{H},{ }^{15} \mathrm{~N}\right)$ correlation spectra with NMR parameters determined on a reference sample of similar composition (see Note 29). In our hands, with the yeast tRNA ${ }^{\text {Phe }}$, high-quality NMR spectra were measured with $2 \mathrm{D}$ $\left({ }^{1} \mathrm{H},{ }^{15} \mathrm{~N}\right)$-BEST-TROSY experiments [16] with 210 transients and interscan delays of $200 \mathrm{~ms}$. Sweep widths were set to 24.0 and $26.0 \mathrm{ppm}$ and $3072 \times 96$ complex points were measured for the ${ }^{1} \mathrm{H}$ and ${ }^{15} \mathrm{~N}$ dimensions, respectively. With these settings, a 2D NMR spectra is recorded in $\sim 120$ min. Record a series of 12 identical spectra in a continuous fashion, for monitoring tRNA maturation during 24 hours.

4. Process the series of spectra with cosine-bell apodization functions and zero filling to 4096 and 512 data points in the ${ }^{1} \mathrm{H}$ and ${ }^{15} \mathrm{~N}$ dimensions, respectively. Other more complicated apodization schemes may also be used to achieve better $\mathrm{S} / \mathrm{N}$ ratios or resolution.

5. Analyze the series of NMR spectra and identify the NMR chemical shift changes that correspond to modification events. For accurate interpretations of the changes appearing upon incubation, an in-depth NMR study may be needed (see Note 30). The acquisition of NMR spectra in a continuous and time-resolved fashion enables the identification of a potential sequential order in the introduction of posttranscriptional modifications. In the case of the yeast tRNA ${ }^{\text {Phe }}$, some modifications appear early in the modification process, such as $455, \mathrm{~m}^{7} \mathrm{G} 46$, and $\mathrm{T} 54$, and some appear late, such as $\mathrm{m}^{1} \mathrm{~A} 58$ (Figure 2).

\section{Notes}

1. The introduction of undesired RNase activity into the transcription reaction can significantly reduce the efficiency of transcription and thereby the overall yield of tRNA production by T7 in vitro transcription.

2. Storage at $-20^{\circ} \mathrm{C}$ significantly prolongs the lifetimes of hydrolysis-sensitive reagents. We usually do not observe any significant deterioration of stored reagents within 1 year at $-20^{\circ} \mathrm{C}$, unless indicated otherwise. Yeast cellular extracts are more sensitive and should be stored at $-80^{\circ} \mathrm{C}$.

3. Protocol for the expression and purification of T7 RNA polymerase in E. coli is not detailed here, but has been described comprehensively elsewhere, and active T7 RNA polymerase can be easily prepared following published protocols $[17,18]$.

4. We usually order the oligonucleotide at $1 \mu \mathrm{mol}$ of synthesis scale with a PAGE purification. The above sequence can simply be changed to produce other tRNAs of interest for studying their maturation with NMR.

5. Efficient transcription are typically obtained from an 18-nucleotide-long $\mathrm{T} 7$ promotor primer: $5^{\prime}$ TAA TAC GAC TCA CTA TAG $3^{\prime}$ [19]. We usually order the oligonucleotide at $0.2 \mu$ mol of synthesis scale purified with a simple desalting step.

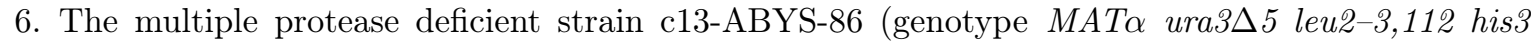
pra1-1 prb1-1 prc1-1 cps1-3) [20] lacks the four major non-specific protease, namely the two 
endoproteinases A and B and the two carboxypeptidases Y and S. Cell extracts prepared from this strain have a much reduced ability to degrade unspecific protein substrates, namely $\sim 1 \%$ of the remaining protease activity as compared to a wild type strain harboring these enzymes [21].

7. Several methods for lysing yeast cells are available, such as pressure chambers (e.g. Eaton press and French press), abrasives (glass bead vortexing), and enzymatic lysis (e.g. zymolyase). In our hands, best enzymatic activity is achieved with mechanical lysis on frozen cells in an Eaton pressure chamber [22]. If an Eaton press is not available in the laboratory, we recommend the use of a French press for cell lysis.

8. Cell extracts may also be snap freezed using an appropriate quantity of dry ice.

9. The composition of the maturation buffer aims at approaching cellular conditions, while at the same time remaining compatible with NMR spectroscopy [23].

10. Precise concentration of the SAM stock solution should be calculated from the millimolar extinction coefficient of SAM at $260 \mathrm{~nm}\left(\epsilon_{260}(\mathrm{SAM})=15.4 \mathrm{mM}^{-1} \cdot \mathrm{cm}^{-1}\right)$ and the measurement of the absorbance at $260 \mathrm{~nm}$ of a suitable dilution of the solution.

11. We recommend preparing SAM stock solutions from SAM p-toluenesulfonate salt (e.g. SigmaAldrich, catalog number A2408). In addition, SAM is not stable in the presence of nucleophiles, and is therefore not stable in basic conditions. Sulfuric acid $\mathrm{H}_{2} \mathrm{SO}_{4}$ is a strong acid with a conjugate base $\mathrm{SO}_{4}^{2-}$ being a poor nucleophile. SAM solutions are quite stable in these conditions, if stored at $-20^{\circ} \mathrm{C}$. Note that the $\mathrm{pH}$ of a $5 \mathrm{mM} \mathrm{H}_{2} \mathrm{SO}_{4}$ solution is $\sim 2$, which may be checked by putting a drop of the SAM stock solution on a $\mathrm{pH}$ indicator paper.

12. Precise concentration of the NADPH stock solution should be calculated from the millimolar extinction coefficient of NADPH at $340 \mathrm{~nm}\left(\epsilon_{340}(\mathrm{NADPH})=6.3 \mathrm{mM}^{-1} . \mathrm{cm}^{-1}\right)$ and the measurement of the absorbance at $340 \mathrm{~nm}$ of a suitable dilution of the solution.

13. We recommend preparing NADPH stock solution from NADPH tetrasodium salt (e.g. SigmaAldrich, catalog number N1630). In addition, NADPH is not stable at acidic pH, therefore adjust $\mathrm{pH}$ of the stock solution to $\mathrm{pH} \sim 8$ by adding a moderately concentrated base (e.g. NaOH $3-5 \mathrm{M})$ drop by drop with a micro-pipette. pH should be checked by putting a drop of the NADPH stock solution on a $\mathrm{pH}$ indicator paper.

14. Other types of NMR tubes, such as standard $5 \mathrm{~mm}$ or $3 \mathrm{~mm}$ tubes may also be used, but volumes of tRNA maturation reactions should be adjusted accordingly.

15. We recommend testing small-scale reactions of $40 \mu \mathrm{L}$ before large-scale production of tRNAs. Transcriptions are performed with each of the four NTPs at $5 \mathrm{mM}$ (total concentration of $20 \mathrm{mM}$ ). Concentration of $\mathrm{MgCl}_{2}$ is varied in small steps in order to evaluate the efficiency of transcription with the $\left[\mathrm{MgCl}_{2}\right] /[\mathrm{NTPs}]$ ratio ranging from 0.3 to 3.0. Concentration of T7 RNA polymerase and DNA template, and the addition of GMP at 2-6 mM need also to be tested in a second step after determination of the best $\mathrm{MgCl}_{2}$ concentration. The set-up and the analysis of small-scale transcriptions with denaturing urea-PAGE can be performed as described in reference [24].

16. Our methodology to monitor posttranscriptional modifications in tRNAs with NMR relies on the fact that imino signals are very sensitive to their chemical environment. Imino groups are carried by uridines and guanosines, and can be observed in $\left({ }^{1} \mathrm{H},{ }^{15} \mathrm{~N}\right)$ correlation spectra on condition that the imino proton is protected from exchange with the solvent by hydrogen bonding. Since adenosines and cytosines do not carry imino groups, it is not necessary to produce a sample that 
is ${ }^{15} \mathrm{~N}$-labeled on As and Cs. This has the advantage of drastically reducing the cost of sample production.

17. After $\sim 1 \mathrm{~h}$ of incubation, a white precipitate of magnesium pyrophosphate becomes most of the time visible and is indicative of an efficient transcription.

18. After addition of EDTA and few minutes of incubation, the solution should turn clear. Magnesium ions are chelated by EDTA, which displaces the equilibrium of magnesium pyrophosphate precipitation. In case of remaining turbidity, add EDTA $0.5 \mathrm{M}$ progressively, by steps of $0.1 \mathrm{~mL}$ until the solution becomes clear.

19. Transcribed RNAs are sensitive to RNases, one should therefore be careful to operate the purification in RNase free conditions. Washing the purification system and the column with $\mathrm{NaOH}$ $0.5 \mathrm{M}$ is sufficient to remove most sources of RNase contamination. In addition, we recommend to run the purification at $4^{\circ} \mathrm{C}$ in a cold room or refrigerated cabinet, but purification may also be performed at room temperature.

20. It is not recommended to load more than $5-6 \mathrm{~mL}$ of transcription onto the column. With larger quantities of tRNAs, the purification becomes indeed difficult due to a broadening of the elution peaks. Repeat steps 5 and 6 as many times as needed for large-scale transcriptions of more than $5 \mathrm{~mL}$.

21. Elution fractions can be analyzed with denaturing urea-PAGE. Yeast tRNA ${ }^{\text {Phe }}$ usually elutes between 50 and $55 \%$ of buffer B in five fractions of $1 \mathrm{~mL}$ each. Do not add fractions of tRNA ${ }^{\text {Phe }}$ eluted after $55 \%$ of buffer B, since they usually contain longer RNA transcripts originating from non-templated nucleotide addition at the 3 '-end of the transcript.

22. For an efficient and extensive dialysis, we usually dialyze the sample against a $2 \mathrm{~L}$ dialysis solution for at least 1-2 hours and change it with a fresh solution three times.

23. We recommend performing the refolding step on diluted tRNAs at a low salt concentration. In the case of the yeast tRNA ${ }^{\text {Phe }}$, we have observed that refolding at high salt and/or in the presence of $\mathrm{MgCl}_{2}$ was less suitable for obtaining tRNAs of high-quality NMR spectra. Refolding with highsalt most probably leads to increased misfolding. However, the situation might be different for the refolding of other tRNAs and should be tested.

24. The yeast tRNA ${ }^{\text {Phe }}$ NMR sample can be stored at $-20^{\circ} \mathrm{C}$ for at least $12-18$ months without observable degradation and alteration of its NMR spectral properties.

25. The weight of the cell pellets can be evaluated by subtracting the weight of an empty conical tube.

26. Final concentrations in the yeast cell extract are as follow: $4 \mathrm{mM} \mathrm{DTT}, 2 \mathrm{mM}$ PMSF, $2 \mathrm{mM}$ benzamidine, and leupeptin, antipain, pepstatin A, and chymostatin each at $2 \mu \mathrm{g} / \mathrm{mL}$.

27. Yeast cellular extracts can be stored at $-80^{\circ} \mathrm{C}$ for at least 12 months without a significant reduction of activity as seen in NMR monitoring of post-transcriptional tRNA modifications.

28. For the maturation studies, we selected a ${ }^{15} \mathrm{~N}$-labeled tRNA concentration of $40 \mu \mathrm{M}$ as a compromise to achieve sufficient signal-to-noise ratio in NMR measurements while seeking to approach cellular tRNA concentrations. As a comparison, the concentration of total tRNAs has been estimated to be $100-200 \mu \mathrm{M}$ in yeast and $200-350 \mu \mathrm{M}$ in E. coli, with typical concentrations of individual tRNAs of $2-15 \mu \mathrm{M}[25,26]$. 
29. To keep the delay between the mixing of the reaction components and start of the NMR experiments as short as possible, we recommend to set-up NMR experiments on a reference sample of similar composition. Specifically, shimming, tuning and matching of the probe and pulse calibrations are performed in advance on this reference sample. In these conditions, tRNA maturation experiments can be quickly started, since only a rapid adjustment of the shims on the real sample is needed.

30. One of the main challenge of NMR monitoring of tRNA maturation is to identify the NMR signature of individual modifications and thus to associate a particular chemical shift change on the NMR spectra with a specific tRNA modification event. For the yeast tRNA ${ }^{\text {Phe }}$, we assigned its imino groups in three forms differing in their modification content [24, 27]. From the analysis of the differences between their $\left({ }^{1} \mathrm{H},{ }^{15} \mathrm{~N}\right)$ chemical shifts, we could identify the NMR signature of individual modifications $[15,27]$. The requirements for such a detailed analysis might be system dependent, but we anticipate that for any system, the complete NMR analysis of at least two tRNA samples, with and without modifications, would be crucial.

31. In the situation where solution stocks of SAM, NADPH and ${ }^{15}$ N-labeled tRNA could not be prepared at the mentioned concentration, please adapt the volumes to reach a final concentration of SAM and NADPH of $4 \mathrm{mM}$ and a final concentration of ${ }^{15} \mathrm{~N}$-labeled tRNA of $40 \mu \mathrm{M}$.

\section{Acknowledgments}

The authors are grateful to Henri Grosjean for protocols and stimulating discussions about RNA modifications, Sylvie Auxilien (I2BC) for the c13-ABYS-86 yeast strain, Bruno Sargueil for guidance regarding the Eaton press implementation, and Christel Le Bon for ensuring the best performance of the NMR infrastructure at the IBPC. The authors acknowledge access to the biomolecular NMR platform of the IBPC that is supported by the CNRS, the Labex DYNAMO (ANR-11LABX-0011), the Equipex CACSICE (ANR-11-EQPX-0008) and the Conseil Régional d'Île-de-France (SESAME grant). This work was supported by grant ANR-14-CE09-0012 from the ANR.

\section{References}

1. El Yacoubi, B., Bailly, M., \& de Crécy-Lagard, V. (2012) Biosynthesis and function of posttranscriptional modifications of transfer RNAs. Annu Rev Genet 46:69-95. https://doi.org/10.1146/annurev-genet-110711-155641

2. Phizicky, E. M. \& Hopper, A. K. (2010) tRNA biology charges to the front. Genes Dev 24:1832-60. https://doi.org/10.1101/gad.1956510

3. Hopper, A. K. (2013) Transfer RNA post-transcriptional processing, turnover, and subcellular dynamics in the yeast Saccharomyces cerevisiae. Genetics 194:43-67. https://doi.org/10.1534/genetics.112.147470

4. Barraud, P. \& Tisné, C. (2019) To be or not to be modified: Miscellaneous aspects influencing nucleotide modifications in tRNAs. IUBMB Life 71:1126-1140. https://doi.org/10.1002/iub.2041

5. Boccaletto, P., Machnicka, M. A., Purta, E., Piatkowski, P., Baginski, B., Wirecki, T. K., de Crécy-Lagard, V., Ross, R., Limbach, P. A., Kotter, A., Helm, M., \& Bujnicki, J. M. (2018) MODOMICS: a database of RNA modification pathways. 2017 update. Nucleic Acids Res 46:D303-D307. https://doi.org/10.1093/nar/gkx1030

6. Helm, M. \& Alfonzo, J. D. (2014) Posttranscriptional RNA Modifications: playing metabolic games in a cell's chemical Legoland. Chem Biol 21:174-85. https://doi.org/10.1016/j.chembiol.2013.10.015

7. Jackman, J. E. \& Alfonzo, J. D. (2013) Transfer RNA modifications: nature's combinatorial chemistry playground. Wiley Interdiscip Rev RNA 4:35-48. https://doi.org/10.1002/wrna.1144 
8. Machnicka, M. A., Olchowik, A., Grosjean, H., \& Bujnicki, J. M. (2014) Distribution and frequencies of post-transcriptional modifications in tRNAs. RNA Biol 11:1619-29. https://doi.org/10.4161/15476286.2014.992273

9. Agris, P. F., Vendeix, F. A. P., \& Graham, W. D. (2007) tRNA's wobble decoding of the genome: 40 years of modification. J Mol Biol 366:1-13. https://doi.org/10.1016/j.jmb.2006.11.046

10. Grosjean, H., de Crécy-Lagard, V., \& Marck, C. (2010) Deciphering synonymous codons in the three domains of life: coevolution with specific tRNA modification enzymes. FEBS Lett 584:252-64. https://doi.org/10.1016/j.febslet.2009.11.052

11. Oberbauer, V. \& Schaefer, M. R. (2018) tRNA-Derived Small RNAs: Biogenesis, Modification, Function and Potential Impact on Human Disease Development. Genes 9:607. https://doi.org/10.3390/genes9120607

12. Lyons, S. M., Fay, M. M., \& Ivanov, P. (2018) The role of RNA modifications in the regulation of tRNA cleavage. FEBS Lett 592:2828-2844. https://doi.org/10.1002/1873-3468.13205

13. Chan, C. T. Y., Pang, Y. L. J., Deng, W., Babu, I. R., Dyavaiah, M., Begley, T. J., \& Dedon, P. C. (2012) Reprogramming of tRNA modifications controls the oxidative stress response by codon-biased translation of proteins. Nat Commun 3:937. https://doi.org/10.1038/ncomms1938

14. Huber, S. M., Leonardi, A., Dedon, P. C., \& Begley, T. J. (2019) The Versatile Roles of the tRNA Epitranscriptome during Cellular Responses to Toxic Exposures and Environmental Stress. Toxics 7:17. https://doi.org/10.3390/toxics7010017

15. Barraud, P., Gato, A., Heiss, M., Catala, M., Kellner, S., \& Tisné, C. (2019) Time-resolved NMR monitoring of tRNA maturation. Nat Commun 10:3373. https://doi.org/10.1038/s41467-019-11356-w

16. Farjon, J., Boisbouvier, J., Schanda, P., Pardi, A., Simorre, J.-P., \& Brutscher, B. (2009) Longitudinal-relaxationenhanced NMR experiments for the study of nucleic acids in solution. J Am Chem Soc 131:8571-7. https://doi.org/10.1021/ja901633y

17. Rio, D. C. (2013) Expression and purification of active recombinant T7 RNA polymerase from E. coli. Cold Spring Harb Protoc 2013:pdb.prot078527. https://doi.org/10.1101/pdb.prot078527

18. Dégut, C., Monod, A., Brachet, F., Crépin, T., \& Tisné, C. (2016) In Vitro/In Vivo Production of tRNA for X-Ray Studies. Methods Mol Biol 1320:37-57. https://doi.org/10.1007/978-1-4939-2763-0_4

19. Milligan, J. F., Groebe, D. R., Witherell, G. W., \& Uhlenbeck, O. C. (1987) Oligoribonucleotide synthesis using T7 RNA polymerase and synthetic DNA templates. Nucleic Acids Res 15:8783-98. https://doi.org/10.1093/nar/15.21.8783

20. Heinemeyer, W., Kleinschmidt, J. A., Saidowsky, J., Escher, C., \& Wolf, D. H. (1991) Proteinase yscE, the yeast proteasome/multicatalytic-multifunctional proteinase: mutants unravel its function in stress induced proteolysis and uncover its necessity for cell survival. EMBO J 10:555-62. https://doi.org/10.1002/j.1460-2075.1991.tb07982.x

21. Achstetter, T., Emter, O., Ehmann, C., \& Wolf, D. H. (1984) Proteolysis in eukaryotic cells. Identification of multiple proteolytic enzymes in yeast. J Biol Chem 259:13334-43.

22. Eaton, N. R. (1962) New press for disruption of microorganisms. J Bacteriol 83:1359-60.

23. Freund, J. \& Kalbitzer, H. R. (1995) Physiological buffers for NMR spectroscopy. J Biomol NMR 5:321-2. https://doi.org/10.1007/BF00211760

24. Catala, M., Gato, A., Tisné, C., \& Barraud, P. (2020) Preparation of Yeast tRNA Sample for NMR Spectroscopy. Bio-protocol 10:e3646. https://doi.org/10.21769/BioProtoc.3646

25. Waldron, C. \& Lacroute, F. (1975) Effect of growth rate on the amounts of ribosomal and transfer ribonucleic acids in yeast. J Bacteriol 122:855-65.

26. Dong, H., Nilsson, L., \& Kurland, C. G. (1996) Co-variation of tRNA abundance and codon usage in Escherichia coli at different growth rates. J Mol Biol 260:649-63. https://doi.org/10.1006/jmbi.1996.0428

27. Catala, M., Gato, A., Tisné, C., \& Barraud, P. (2020) 1H, 15N chemical shift assignments of the imino groups of yeast tRNAPhe: influence of the post-transcriptional modifications. Biomol NMR Assign 14:169-174. https://doi.org/10.1007/s12104020-09939-6 


\section{a $\quad$ step 1}

tRNA transcription with ${ }^{15} \mathrm{~N}$-labeled nucleotides

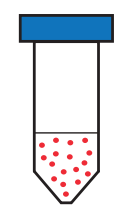

tRNA in vitro transcription

\section{b step 2}

Unlabeled cell extract preparation

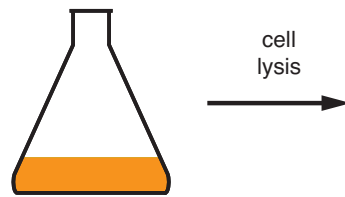

cell

culture

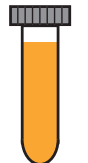

tRNA purification by ion-exchange chromatography
tRNA dialysis and concentration

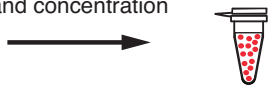

${ }^{15} \mathrm{~N}$-labeled

\section{c step 3}

NMR monitoring of tRNA maturation

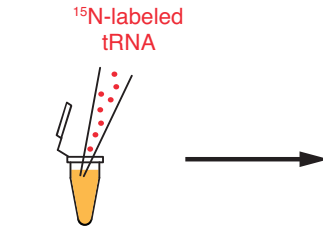

unlabeled cellular extract

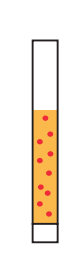

in extract NMR sample

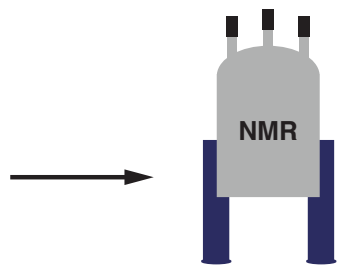

incubation and NMR measurements in the spectrometer

ultra-centrifugation of the cell debris

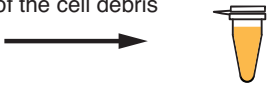

unlabeled cellular extract

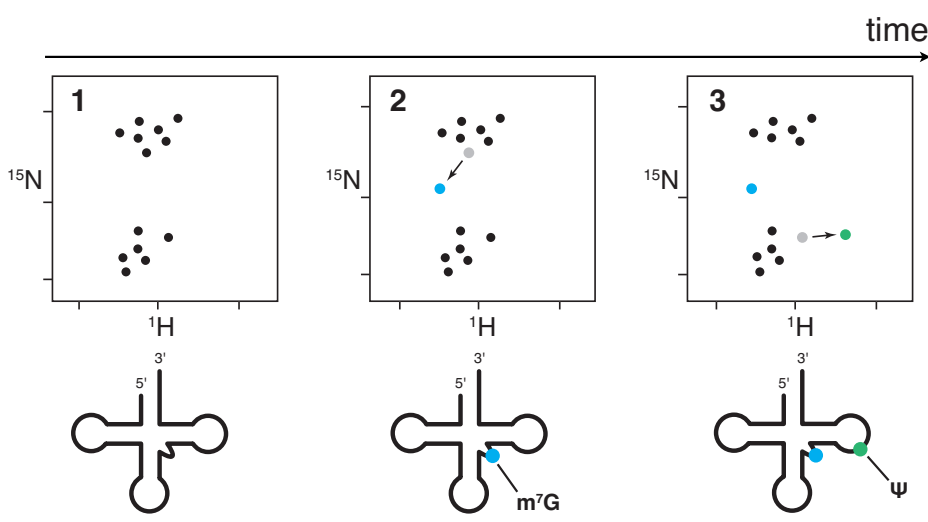

Figure 1. Schematic description of the method. (a) Step 1: tRNA transcription with ${ }^{15} \mathrm{~N}-$ labeled nucleotides. A ${ }^{15} \mathrm{~N}$ labeled tRNA (represented as red dots) is produced by $\mathrm{T} 7$ in vitro transcription. The transcription reaction is purified by ion-exchange chromatography (MonoQ column), and the purified ${ }^{15} \mathrm{~N}$-labeled tRNA is dialyzed and concentrated for use in step 3. (b) Step 2: unlabeled cell extract preparation. A cell culture is performed in an Erlenmeyer flask with unlabeled growth media. After cell lysis, cell debris are removed by ultracentrifugation, leading the unlabeled cellular extract subsequently used in step 3. (c) Step 3: NMR monitoring of tRNA maturation. The ${ }^{15}$ N-labeled tRNA produced in step 1 is introduced in the unlabeled cellular extract produced in step 2. This mix is transferred to an NMR tube to yield an in extract NMR sample. The tRNA maturation sample is incubated directly in the NMR spectrometer. Successive NMR measurements are performed to provide time-resolved information on the tRNA maturation process. NMR chemical shift changes (indicated with arrows on the NMR spectra) are identified and linked to specific modification events. The acquisition of NMR spectra in a continuous and time-resolved fashion enables the identification of a sequential order in the introduction of posttranscriptional modifications. 
a

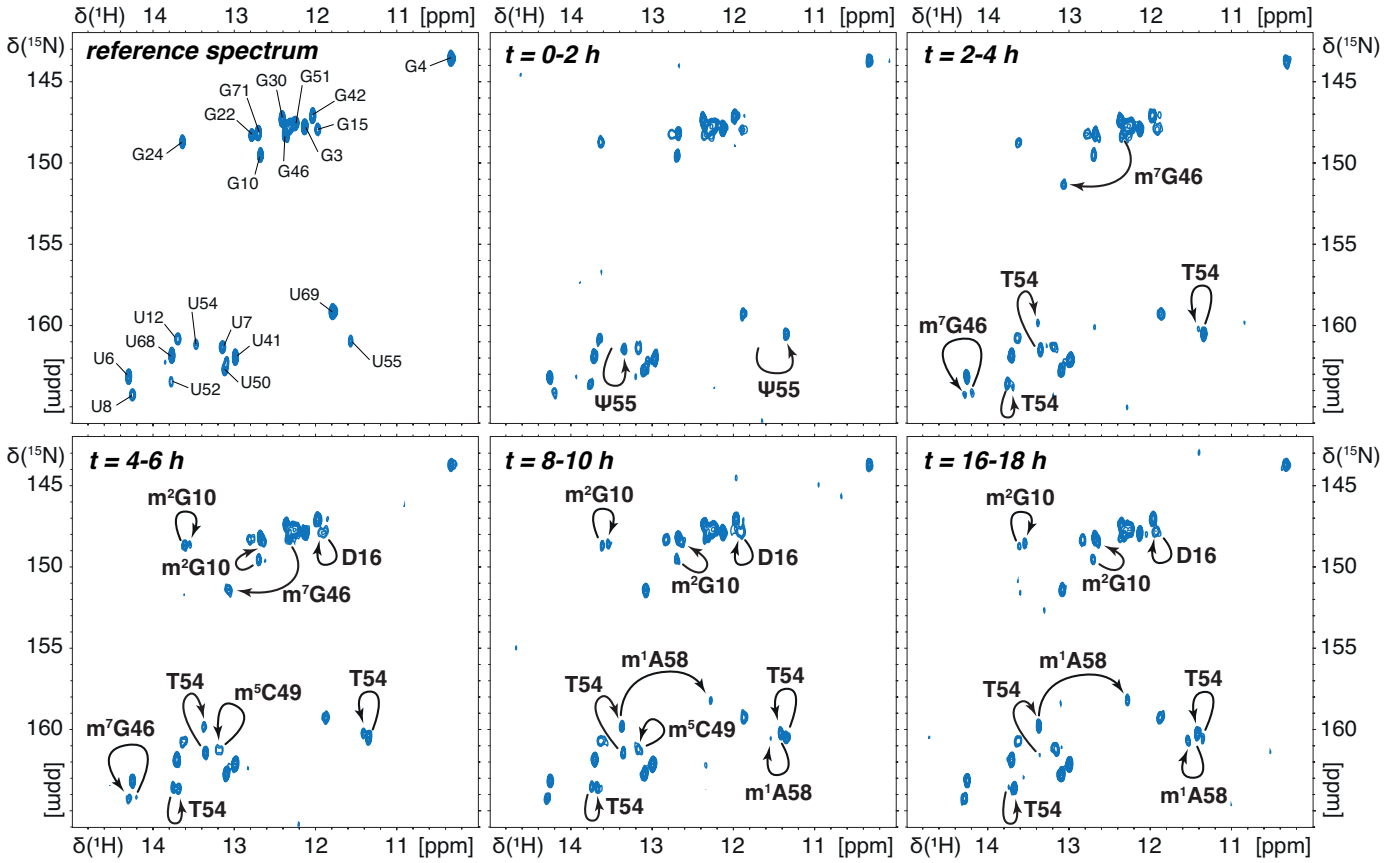

b

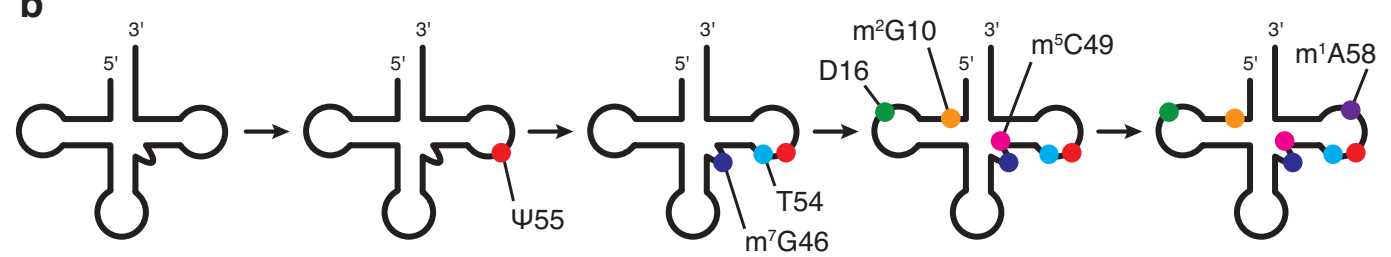

Figure 2. Time-resolved NMR monitoring of RNA modifications in yeast tRNA ${ }^{\text {Phe }}$. (a) Imino $\left({ }^{1} \mathrm{H},{ }^{15} \mathrm{~N}\right)$ correlation spectrum of a ${ }^{15} \mathrm{~N}$-labeled yeast tRNA ${ }^{\text {Phe }}$ measured in vitro to provide a reference spectrum (first top left spectrum) and in a time-resolved fashion during a continuous incubation at $30^{\circ} \mathrm{C}$ in yeast cellular extract over $18 \mathrm{~h}$ (remaining five spectra). Each NMR spectrum measurement spreads over a 2 hours time period (incubation time indicated on each spectrum). Modifications occurring at the different steps are reported with arrows. (b) Schematic view of the sequential order of the introduction of modifications in yeast tRNA ${ }^{\text {Phe }}$ as observed with NMR. 